\title{
The legacy of Bismarck
}

\author{
Gordon Tullock
}

Received: 18 February 2009 / Accepted: 18 February 2009 / Published online: 10 March 2009

(c) Springer Science+Business Media, LLC 2009

That Otto von Bismarck (1815-1898) was a great man I do not deny. He was not unduly honest, though, and one of his most deceptive programs has been adopted all over the world. In the United States, every worker pays a wage tax of $10 \%$ and is then given a pension in old age. The retirement age was set at 60 initially, but has been raised since. Because many older people, including myself, continue to work, GDP is not much affected. ${ }^{1}$

Now note the Bismarckian fraud: The worker is told that his payroll tax is $5 \%$ of wages and that his employer pays the other $5 \%$. Bismarck was a clever man; most workers do not realize that, since their wages are reduced by $5 \%$, they pay the tax in full. (There is a modest income tax benefit in this scheme because the employer's contribution is not included in the worker's taxable income.)

I suggest that the employer's share of the payroll tax be repealed and, at the same time, wages be increased proportionately. The worker's higher nominal income would raise his income tax bill, but that effect could be offset by appropriate changes to the tax code. I leave the details to those who know more about tax accounting than I do.

The principal advantage of this proposal would be to make the system more open and honest. Currently it is a politically advantageous fraud. The worker thinks that his income is larger than it is and that his employer pays part of the tax.

I hope that readers will comment on this suggestion and perhaps write their elected representatives. Bismarck was very clever, however, and I suspect that the fraud will continue.

\footnotetext{
${ }^{1}$ I have now retired at 86.

G. Tullock (凶)

6840 E. Via Colorada, Tucson, AZ 85750-6301, USA

e-mail: gtullock@gmu.edu
} 